\title{
KESENIAN LARAS MADYA SEBAGAI MATERI PELAJARAN SENI BUDAYA DALAM LIMA ORIENTASI NILAI PENDIDIKAN GAGE DAN BERLINER
}

\author{
Sagaf Faozata Adzkia \\ Prodi Pendidikan Seni, Program Pascasarjana Universitas Negeri Semarang \\ E-mail: adzkia_sagaf@yahoo.com
}

\begin{abstract}
Abstrak
Berkaitan dengan UU Sistem Pendidikan Nasional Tahun 2003. Menuntut seni diwajibkan masuk dalam kurikulum pendidikan nasional sebagai mata pelajaran seni budaya (UU SISDIKNAS No. 20 Tahun 2003, Pasal 37). Pendidikan seni tergolong dalam pendidikan humanistik yang mencakup pendidikan nilai guna membentuk kecerdasan melalui cara berfikir yang kreatif. Gage dan Berliner menjelaskan lima orientasi nilai dalam pendidikan seni yang harus mengarah pada peningkatan nilai kepribadian, kecakapan hidup, kreativitas dan kognisi, meningkatkan rasa keingin tahuan, dan dapat menimbulkan kepekaan (Brian Hill, 1999:1). Kesenian Laras Madya sebuah perpaduan budaya Islam Jawa yang syarat dengan kandungan nilai, akan berguna bagi perkembangan karakter personal. Kesenian Laras Madya relevan untuk diaplikasikan dalam dunia pendidikan sebagai salah satu materi pelajaran seni budaya dalam pendidikan formal yang memenuhi lima orientasi nilai Gage dan Berliner. Tiga pembahasan dalam penulisan ini diantaranya deskripsi kesenian Laras Madya, relevansi kesenian Laras Madya sebagai materi pelajaran seni budaya, dan Laras Madya dalam lima orientasi nilai pendidikan Gage dan Berliner. Sebagai upaya pelestarian budaya dan pendukung kemajuan pendidikan di Indonesia.
\end{abstract}

Kata Kunci: Kesenian Laras Madya, Pendidikan Seni, Orientasi Nilai Pendidikan Gage dan Berliner

\section{LARAS MADYA AS THE MATERIAL IN ART AND CULTURE SUBJECT IN GAGE AND BERLINER'S FIVE VALUE ORIENTATIONS}

\begin{abstract}
Related with the National Education System Act of 2003, Oblige art is required to enter the national education curriculum as a subject of art and culture (Education Law No. 20 of 2003, Article 37). Art education belongs to the humanistic education to shape intelligence value through creative way of thinking. Gage and Berliner describe five value orientations in art education that should lead to an increase in the value of personality, life skills, creativity and cognition, in the sense of curiosity and sensitivity (Brian Hill, 1999: 1). The art of Laras Madya, an Islamic Javanese culture which has a lot of values, would be useful for the development of personal character. The art of Laras Madya will be a relevant object to be applied in the subject of art and culture in
\end{abstract}


formal education, that meets Gage and Berliner's five value orientations. Three points of discussion include the description of Laras Madya, the relevance of Laras Madya to become the subject of art and culture, and Laras Madya in five educational value orientations of Gage and Berliner as an effort to support cultural preservation and advancement of education in Indonesia.

Keywords : The Art Of Laras Madya, Art Education, Education Value Orientations of Gage and Berliner

\section{PENDAHULUAN}

Pemberlakuan UU Sistem Pendidikan Nasional Tahun 2003, menuntut seni diwajibkan masuk dalam kurikulum pendidikan nasional, sebagai mata pelajaran senibudaya (UU SISDIKNAS No. 20 Tahun 2003, Pasal 37) ditinjau dari esensi seni itu sendiri, maka pendidikan seni tergolong dalam pendidikan humanistik yang mencakup pendidikan nilai. Pendidikan humanistik yang berlandaskan nilai mengarahpada pemahaman pengetahuan diperoleh dan dibentuk melalui artistik dapat mebentuk kecerdasan melalui cara brfikir yang kreatif.

Sehubungan dengan keberadaan seni sebagai disiplin yang sarat dengan nilai maka Gage dan Berliner menjelaskan lima orientasi nilai dalam pendidikan seni, sebagai berikut (Brian Hill 1999:1):

1. pendidikan harus mengarah pada peningkatan nilai kepribadian (DevelopmentRegulatory),

2. pendidikan harus dapat mengembangkan kecakapan hidup (regulatory affective),

3. pendidikan harus dapat meningkatkan kreativitas dan koognisi (Creativity \&cognition),

4. pendidikan harus dapat meninggkatkan rasa keingin tahuan.

5. pendidikan harus dapat menimbulkan kepekaan

Pendidikan ini bisa melalui kegiatan apresiasi, kreasi, dan pengkajian nilai-nilai budaya dari sebuah karya seni. Apresiasi dapat diwujudkan melalui melihat dan mengamati seni, melalui proses ini siswa dapat dilatih untuk mengembangkan sikapsikap menghargai sebuah karya dan pencipta karya. Kreasi akan muncul setelah siswa mempunyai pengalaman dalam berapresiasi lalu mewujudkanya dalam sebuah karya 
sederhana dengan mempresentasikan nilai-nilai yang terkandung didalamnya dan mengaplikasikan dalam kehidupan sehari-hari.

Kesenian tradisional merupakan salah satu materi yang relevan dalam pendidikan seni budaya, mempelajari budaya sendiri memungkinkan siswa lebih luwes dalam pelaksanaanya begitupun adaptasi terhadap pembelajaran lain diluar permasalahan budaya, tidak ada budaya yang bersifat konstan atau tidak berubah. Kebudayaan tetap responsif terhadap perubahan kondisidari dunia fisik. Oleh karena itu kebudayaan bersifat dinamis (Liliweri, 2014:33). Hal tersebut memungkinkan peserta didik untuk menumbuhkan sifat dinamis dan menekankan kecintaan terhadap budaya sendiri dimana hal tersebut merupakan kriteria normatif kaitan antara kemampuan berapresiasi pada seni dengan rasa cinta terhadap bangsa dan tanah air (Bastomi, 1988:46).

Kesenian Laras Madya merupakan salah satu kesenian tradisional perpaduan budaya Islam Jawa yang syarat dengan kandungan-kandungan nilai luhur yang berguna bagi perkembangan karakter personal. Bahwa setiap peserta didik yang berinteraksi dengan lingkungan seni berupa bahan pelajaran yang bermuatan nilai estetik, apapun bentuk serta jenisnya akan menumbuhkan sadar estetik (Soeharjo, 2012: 159), maka

penulis menganggap kesenian tersebut menarik jika diaplikasikan dalam dunia pendidikan sebagai salah satu materi dalam mata pelajaran seni budaya melalui proses pewarisan pendidikan formal sebagai upaya pelestarian. Untuk mewujudkan hal tersebut ada tiga permasalahan yang dapat diajukan guna memahami hakiki dari kesenian Larasmadya dan relevansinya dalam dunia pendidikan, yaitu:

(1). Apakah yang dimaksud dengan kesenian Laras Madya? (2). Bagaimanakah relevansi kesenian Laras Madya sebagai materi pelajaran seni budaya? (3). Bagaimanakah kesenian Laras Madya dalam lima orientasi nilai pendidikan Gage dan Berliner?

\section{KESENIAN LARAS MADYA}

Masyarakat Jawa mengenal solawat Laras Madya sebagai tembang tengahan, laras bisa berarti harmoni ataupun sebuah tangga nada, madya berarti tengah, maka dapat diartikan sebuah kesenian musik yang memiliki nilai keseimbangan dalam memahami nilai-nilai kehidupan. Jika masyarakat pesisir mengenal sholawat dengan panduan lirik Al-barjanzi, Burdah, Diba, atau Shimtut Durar, maka kesenian Laras 
Madya mempedomani serat Wulangreh hasil karya Pakubuwono ke IV di kasunanan Surakarta. Serat Wulangreh berisikan tuntunan hidup Jawa Islam agar manusia senantiasa menuju kematangan dan kedewasaan.

\section{Sejarah Singkat Kesenian Laras Madya}

Kesenian Laras Madya berawal muncul di keraton Surakarta pada abad 20 akhir abad 19 dan hanya dipentaskan di dalam keraton saja bukan dipertotonkan untuk umum, tapi pada pemerintahan Pakubuwono X (1893-1930) seni laras madya tidak hanya diajarkan di Keraton saja tapi mulai diajarkan di luar keraton. Perkembanganya di Sleman berawal di tahin 1963 kesenian ini dibawa oleh Mohamad Salman, ia merupakan anak abdi dalem keraton surakarta yang bernama Faqih Ibrahim yang sangat akrab dengan Pakubuwono $\mathrm{X}$, yang kemudian mendapat amanah untuk menyebarkan seni laras madya ke luar keraton Surakarta. Sampai sekarang kesenian Laras Madya masih dijumpai keberadaanya di Sleman Yogyakarta (Noviyanti, 2010: 6). Dalam penyajiannya kesenian Laras Madya menggunakan iringan instrumen kendang, terbang gong, terbang dhana, saron dua bilahan, penembang yang disebut Bowo dan Gerong. Hal tersebut merupakan salah satu wujud kreativitas yang dilakukan oleh para penyebar agama Islam untuk melakukan perpaduan nilai-nilai Islam dengan budaya Jawa agar Islam sebagai agama dapat diterima secara sadar, tanpa paksaan dan damai sehingga tidak menimbulkan berbagai goncangan besar dan kekerasan di masyarakat sebagaimana ciri khas budaya jawa yang mengutamakan keharmonisan (Sulasman dan Gumilar, 2013: 173).

\section{Instrumen Musik Kesenian Laras Madya}

Instrumen musik yang digunakan dalam kesenian Laras Madya hampir sama dengan sholawatan pesisiran tetapi perbedaannya ada pada penggunaan instrumen Saron dengan dua bilahan. Saron tersebut dalam penggunaanya hampir mirip dengan kempul pada kesenian karawitan yang memiliki dua karakter suara ning dan nong, karakter suara tersebut menjadikan penyajian musik pada kesenian Laras Madya memiliki kekhasan. Berikut penjelasan instrumentasi dalam kesenian laras madya:

- Kendang 


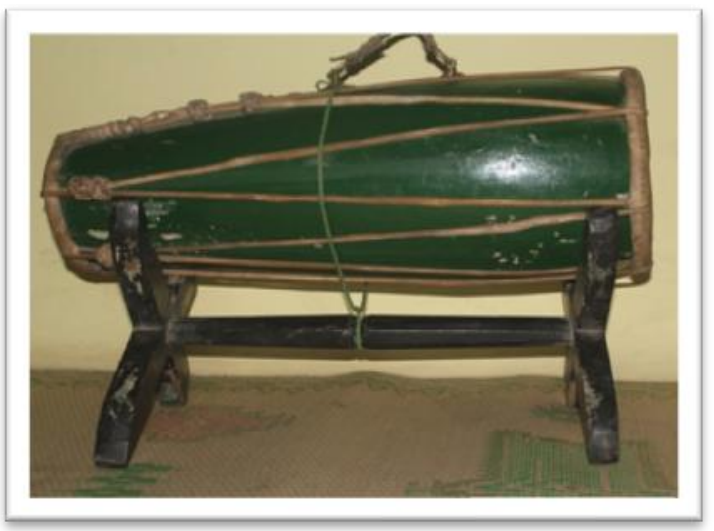

Gambar 1. (Instrumen Musik Kendang)

Dok. Penulis

Merupakan sebuah instrumen perkusi yang berasal dari kebudayaan Jawa dengan sebuah tabung yang terbuat dari kayu, (kayu nangka, kayu mahoni) dengan membran dari bentangan kulit lembu. Kendang merupakan alat musik membranofon, sebagai pengisi perkusi pada orkestra gamelan, keberadaanya tersebar sehingga juga terdapat kendang Sunda, kendang Jawa, kendang Bali, dalam cirikhas masing-masing yang berbeda. Dalam kesnian Laras Madya yang digunakan adalah kendang Jawa tunggal, dimana hanya terdapat satu buah kendang. Berfungsi guna mengatur tempo dan memimpin instrumen lain layaknya konduktor dalam orkestra. Lambat dan cepatnya penyajian kesenian tersebut tergantung komando dari penabuh kendang.

- Terbang Gong dan Terbang Dhana

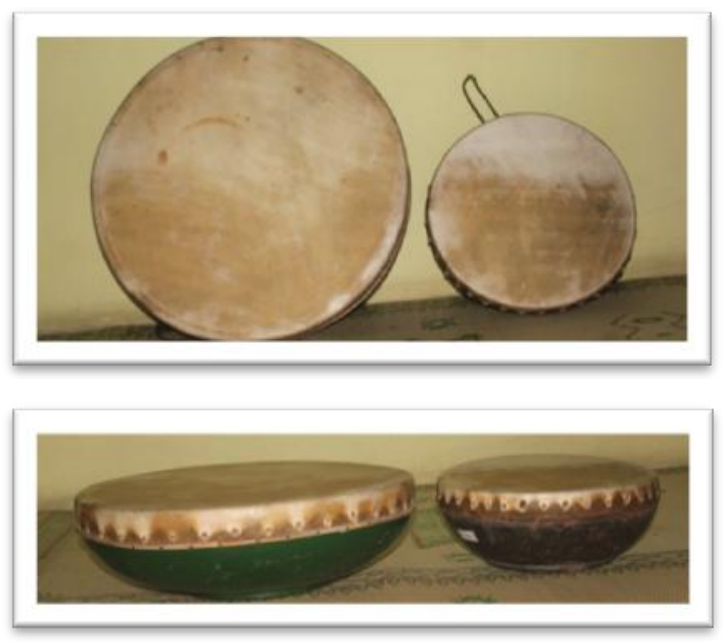

Gambar 2. (Instrumen Musik Terbang Gong dan Terbang Dhana) Dok. Penulis

- $\quad$ Terbang Gong 
Merupakan instrumen perkusi dari kebudayan islam, berdiameter terbesar melebihi ukuran kendang dan Terbang Dhana, memiliki diameter lingkaran 50-60 cm. Terbang Gong berfungsi sebagai bass, mengisi ritmik sederhana pada setiap permulaan dua birama sekali, menjadikan musik yang tersaji terdengar berat dan berbobot.

- Terbang Dhana

Instrumen ini memiliki kemiripan dengan terbang gong namun berukuran lebih kecil. Terbang Dhana memiliki diameter lingkaran $40 \mathrm{~cm}$. Instrumen ini berfungsi sebagai isian variasi perkusi yang mengikuti kekosongan ritmik dengan komando tempo dari kendang. Terbang Dhana penting karena menjadikan penyajian musik Laras Madya terdengar penuh.

- Saron Dengan Dua Bilahan

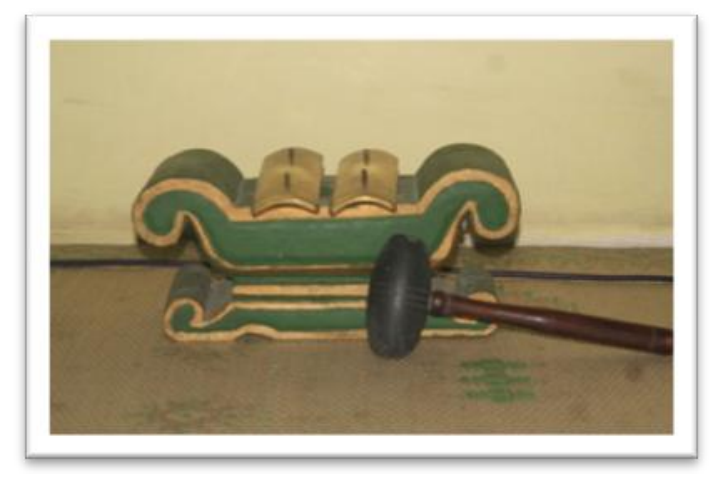

Gambar 3. (Instrumen Musik Saron Dua Bilahan)

Dok. Penulis

Saron merupakan salah satu instrumen gamelan yang termasuk dalam keluarga balungan, biasa disebut juga "ricik". Ditabuh dengan cara dipukul dengan alat pemukul menyerupai palu yang terbuat dari kayu, keunikanya dalam kesenian Laras Madya, saron yang dipakai hanya memiliki dua buah bilah balungan, bernada 6 dan 7 (nem dan pi). Merupakan dua rangkaian bilah dari perunggu terlihat kecil diantara instrumen-instrumen yang lainya, memiliki warna suara yang unik berbunyi " ning dan nong" yang merupakan warna suara ciri khas kesenian musik Laras Madya.

- Pelantun Tembang 


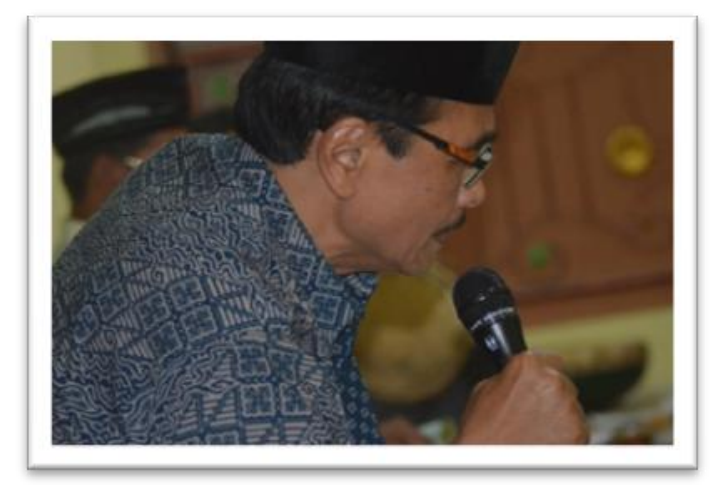

Gambar 4. (Pelantun Tembang)

Dok. Penulis

Kesenian Laras Madya beranggotakan pelantun tembang yang disebut Bowo dan Gerong. Bowo merupakan penyanyi bait-bait pembuka, semacam intro yang tidak diiringi musik. Lazimnya Bowo dibawakan oleh seseorang yang dianggap mumpuni, sesepuh atau pemimpin kelompok. Seorang yang berperan sebagai Bowo ini harus benar-benar ahli tembang, karena Bowo merupakan leader untuk memulai lagu, maka suara pelantunnya harus benar-benar mantap. Hanya saja, dari satu tembang ke tembang berikutnya, bowo tidak dibawakan oleh seorang saja, namun kadang berganti dengan personil lain yang sama-sama mumpuni.

Gerong merupakan pemain Laras Madya yang tidak memainkan alat musik namun berpartisipasi dalam memberikan "Senggakan" atau aksentuasi vokal dan "tepuk tangan" sebagai pengiring ritmikal yang melengkapi penyajian musik Leras Madya. Senggakan bisa berupa suara-suara sahutan yang menutup (seperti sebuah kata yha'e..!!), menyusuli ataupun menyelaraskan ketukan dengan irama tembang. Adapun iringan tepukan tangan berfungsi merampakkan alunan musik sehingga menjadi hidup dan meriah. Gerong sangat terbuka bagi partisipasi audiens asalkan tidak merusak keseriusan penyajian. 


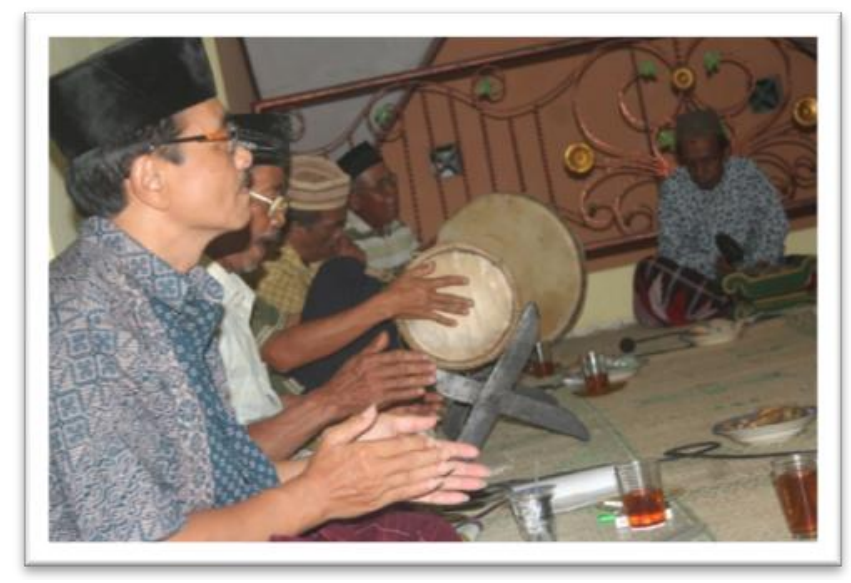

Gambar 5. (Penyajian Kesenian Laras Madya)

Dok. Penulis

\section{Bentuk Penyajian}

Bentuk penyajian kesenian Laras Madya diawali dengan suluk oleh penyaji tembang utama (Bowo). Suluk dalam kesenian ini berfungsi sebagai intro dengan penyampaian bait pembuka dari syair serat Wulangreh. Merupakan sebuah musikalisasi syair dibawakan secara solo, improvisasi dengan menggunakan modus tangga nada/ laras slendro. Laras slendro merupakan salah satu rangkaian nada pentatonik Jawa yang terdiri dari lima nada. Variasi ritmik dan interval nada dari modus tersebut dibawakan berdasarkan kebebasan penembang utama, semakin bervariasi ritmik, interval, dan intensitas tempo menandakan kepiawaian seorang Bowo.

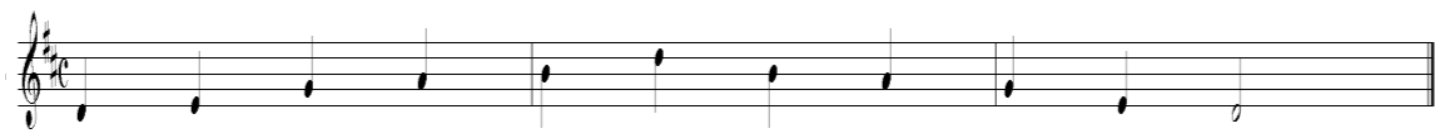

Gambar 6. (Modus/ Tangga Nada Pentatonik Slendro)

Dok. Penulis

Usai penyajian suluk, kendang akan memberikan ritmik aba-aba (feel in) sebagai isyarat tembang dimulai dan setiap penyaji instrumen mulai memainkan musik sesuai peranannya. Kendang memegang kendali tempo berperan sebagai konduktor, diawali dengan enerjik dan semakin kelamaan lagu dibawakan semakin sumeleh atau santai sesuai sifat syair yang dibawakan. Terbang Gong di tabuh setiap awal birama dan bersahut kemudian di dua birama berikutnya, berfungsi sebagai bass mengisi low sound untuk memenuhi suara berat dan berbobot. Terbang Dhana mengisi ritmik menegaskan suara kendang untuk menghindarkan penyajian dari kekosongan suara. Saron sebagai 
ciri khas mengisi suara di setiap ketukan kedua sampai ketukan keempat dalam setiap birama. Gerong/ penyanyi pendamping berperan sebagai pelengkap atau penegas lagu menyahuti penyanyi utama, bisa dengan mengikuti melodi utama autau memberikan senggakkan-senggakkan. Bentuk ansambel tersebut merupakan pengulanganpengulangan/ repetisi, setiap lagu dibawakan serupa dibedakan oleh variasi tempo dan dinamik sesuai sifat syair yang dibawakan, serta perbedaan variasi suluk yang dibawakan oleh Bowo. Berikut contoh notasi tema bentuk musik Laras Madya dalam delapan birama:

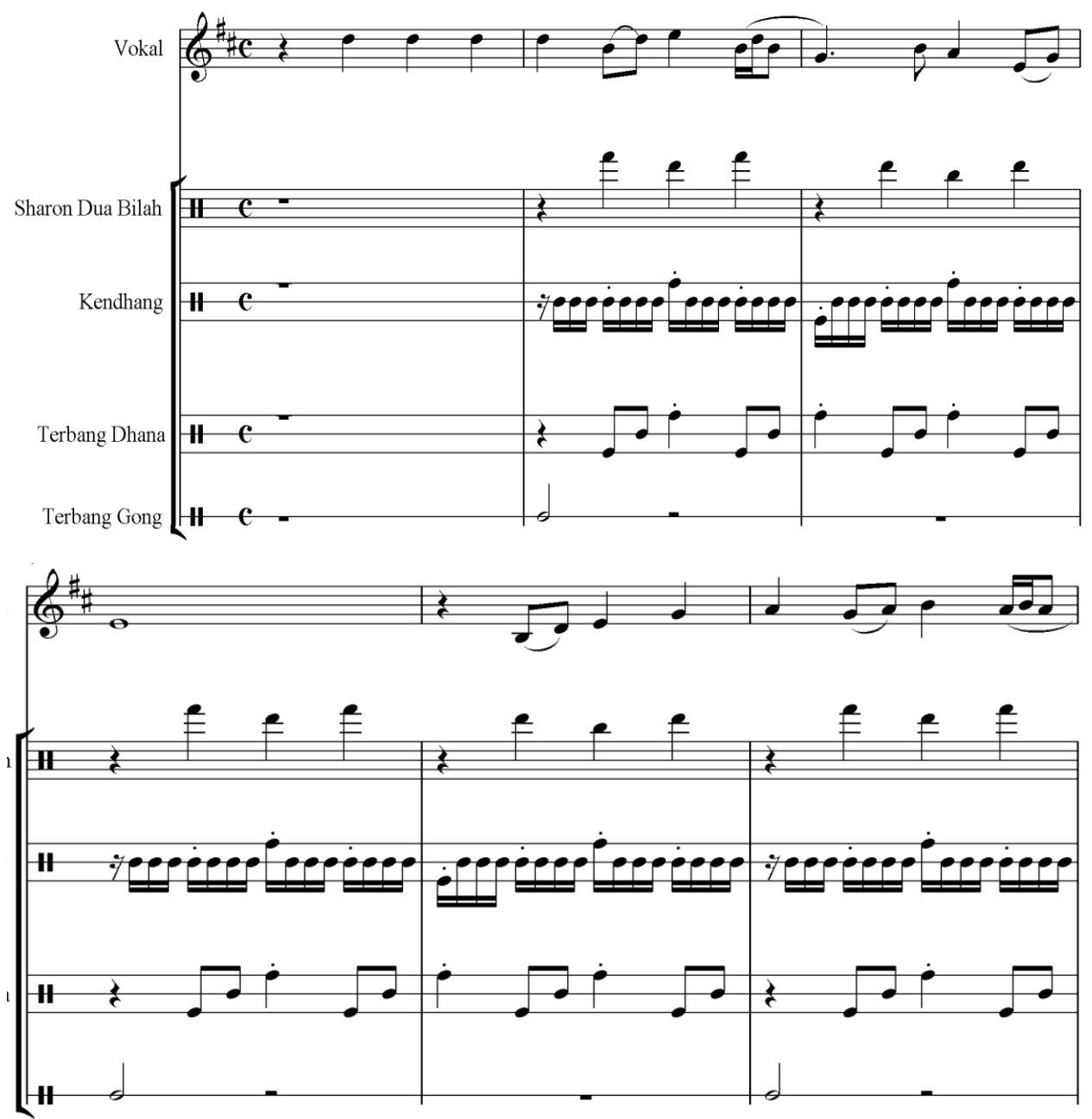




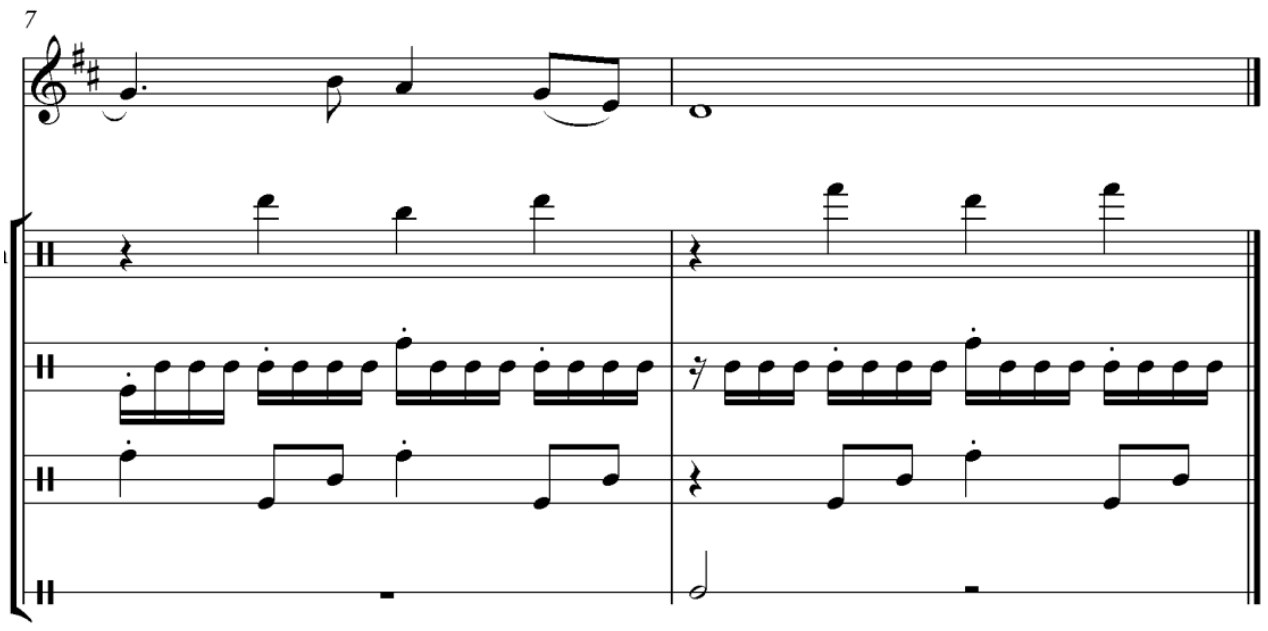

Gambar 7. (Notasi Tema Bentuk Musik Laras Madya)

Dok. Penulis

- Contoh salah satu lirik pada tembang laras madya:

Sasmitaning ngaurip puniki,

yekti ewuh yen ora weruha,

tan jumeneng ing uripe,

sakeh kang ngaku-aku,

pangrasane pan wus utami,

tur durung wruh ing rasa,

rasa kang satuhu,

rasaning rasa punika,

upayanen dhara pon, sapurneng dhiri, ing kaupanira.

Jroning Qur'an nggoning rasa jati,

nanging pilih wong kang uninga,

anjaba lawan tuduhe nora kena binawur,

ing satemah nora pinanggih,

mundak katalanjukan,

temah sasar-susur,

yen sira ayun waskitha,

kasampurnaning badanira puniki, sira anggegurua.

(Pupuh Dhandhanggula pada 2-3)

- Terjemahan:

Maka kehidupan itu

sungguh sayang sayang bila tak tahu,

tidak kokoh hidupnya,

banyak orang mengaku,

perasaanya sudah utama,

padahal belum tahu rasa,

rasa yang sesungguhnya, 
hakikat rasa itu adalah,

usahakan supaya diri sempurna,dalam kehidupan.

Dalam Qur'an tempat rasa jati

tapi jarang orang tahu,

keluardari petunjuk,

tak dapat asal-asalan,

ahirnya tidak ketemu,

malahan terjerumus,

akhirnya kesasar,

kalau kamu ingin peka,

agar hidupmu sempurna,

maka bergurulah.

(Merupakan sebuah syair "kriteria guru yang baik"menurut Paku Buwana IV)

\section{Relevansi Kesenian Laras Madya Sebagai Materi Pelajaran Seni Budaya}

Seni memiliki empat macam kategori yaitu seni untuk kalangan elit / The Art Of Cultural Elite, kesenian rakyat / Folk Art, seni populer atau seni kalangan urban / Popular Art, dan seni yang dipertunukkan melalui media masa / Mass Art (Hauser, 1982: 556). Kesenian Laras Madya masuk kedalam kategori kesenian rakyat (Folk Art). Seni ini ditentukan oleh norma-norma yang telah dibuat dan disepakati masyarakat, seni adalah cerminan masyarakat yang terdiri dari jiwa masyarakat, keinginan masyarakat, realitas masyarakat, dan keinginan masyarakat. Seni dalam lingkup masyarakat lebih menekankan fungsi, penuh simbol dan makna. Meski tak lepas dari pemahaman sederhana bahwa seni merupakan usaha untuk menciptakan bentuk-bentuk yang menyenangkan (Herbert, 2000: 2). Jika dipandang dari dua kutipan diatas kesenian Laras Madya relevan kiranya jika diaplikasikan sebagai materi pelajaran seni budaya karena memiliki fungsi dan makna pada masyarakat sebagai pembentuk karakter siswa dalam kehidupan sosial dan merupakan hal yang menyenangkan sebagai objek materi pelajaran.

Kesenian Laras Madya mengalami banyak perubahan mengikuti perkembangan zaman. Manusia memiliki dorongan utuk bereksplorasi, mencari kemungkinankemungkinan lain dari pada yang sehari-hari sudah ada dihadapinya (Sedyawati, 2006: 35). Perubahan musik Laras Madya tersebut bisa muncul dari dalam atau ide-ide para palaku, ataupun inspirasi dari luar seperti pengaruh musik-musik populer yang ada, adapun dunia pendidikan sebagai kontrol agar kesenian tersebut tidak mengalami perubahan ke arah yang merugikan namun tetap terjaga kelestarianya dengan baik, 
karena sekolah adalah sarana belajar formal yang tak lepas dari kaidah-kaidah institusional.

Kesenian Laras Madya dapat dikategorikan sebagai kesenian rakyat, maka erat kaitanya dengan seluk beluk kehidupan masyarakat sebagaimana kesenian tersebut mempengaruhi keseimbangan fungsi dan struktur masyarakat setempat melalui peranan masing-masing pelaku kesenian, musik yang dimainkan, nilai isi dari kandungan syair yang dibawakan. Aktivitas seni dapat memberikan fungsi pada perkembangan pribadi seseorang (terutama anak-anak). Kontribusi yang dimaksud berkaitan dengan pemberian ruang berekspresi, pengembangan potensi kreatif dan imajinatif, peningkatan kepekaan rasa, menumbuhkan rasa percaya diri, dan pengembangan wawasan budaya (Jazuli, 2014: 51). Hal tersebut memungkinkan untuk digunakanya kesenian Laras Madya sebagai salah satu materi pelajaran seni budaya.

\section{Kesenian Laras Madya dalam lima orientasi nilai pendidikan menurut Gage dan Berliner}

Kesenian musik Laras Madya dapat mengarahkan siswa pada peningkatan nilai kepribadian (Development Regulatory), menjadi pribadi yang sadar akan akar budayanya adalah hal yang penting pada dunia pendidikan di tengah gencarnya serangan budaya massa dari berbagai media. Tayangan televisi yang semakin diragukan nilai positifnya bebas diserap anak-anak dengan penayangan yang acak, media internet tanpa pengawasan dengan mudahnya di akses anak-anak usia sekolah, game dengan segmentasi umur pengguna yang bebas diakses, hal tersebut merupakan ancaman nyata yang begitu menakutkan bagi anak usia pelajar jika tak ada penyeimbang kegiatan positif yang dapat dilakukan. Nilai-nilai luhur adi luhung Jawa dapat terserap dari komunikasi dan kaidah-kaidah pemahaman kesenian Laras Madya tersebut baik dalam berapresiasi ataupun berkreasi melalui bimbingan guru.

Kesenian Laras Madya dilakukan dalam bentuk ansambel musik perpaduan budaya Jawa dan Islam. Ansambel erat kaitanya dengan pemahaman komunikasi masing-masing individu untuk mengkombinasikan peran masing-masing pelaku kesenian, Komunikasi antar penabuh instrumen kendang, terbang gong, terbang dhana, sharon, dan penyaji vokal, merupakan sebuah keselarasan peran. Masing-masing bermain musik sesuai dengan porsinya, tak ada yang lebih menonjol melengkapi satu 
sama lain. Sehingga seandainya dalam penyajiannya berkurang satu penyaji maka akan terasa ketimpangannya. Pengertian tersebut adalah alasan dalam mengembangkan kecakapan hidup (regulatory affective), dengan komunikasi aktif dalam sebuah permainan musik Laras Madya, dapat dijadikan masukan positif pada kehidupan nyata. Seperti kepercayaan diri dalam sebuah komunikasi, kepercayaan diri dalam menunjukkan kemampuan, bersosialisasi antar kawan, keluarga, dan guru.

Pendidikan harus dapat meningkatkan kreativitas dan kognisi (Creativity \& cognition). Penyampaian pembelajaran kesenian Laras Madya melalui berbagai macam metode menuju apresiasi dan kreasi oleh pengajar dapat membangkitkan stimulus siswa dalam memahaminya, tentunya dengan penyampaian yang menarik melalui pola divergen, pola dua arah dimana siswa ikut aktif menanggapi penyampaian guru dengan berbagai kemungkinan jawaban yang difikirkan oleh siswa. Dimana siswa diharapkan aktif merespon penyampaian seorang pengajar yang tidak hanya terkotakkan pada pemahaman benar dan salah saja. Kreativitas siswa tak lepas dari kreativitas seorang guru. Penyampaian kesenian Laras Madya dari sejarah dengan kemasan sesuai segmentasi pelajar akan mudah diserap, bisa dalam bentuk kemasan cerita dongeng sejarah terbentuknya, tokohnya, instrumentasinya, nilai, dan fungsi dalam masyarakat. Dalam pengapliasianya siswa akan mengalami rangsangan kreativitas untuk berkreasi/ mempraktekkan kesenian tersebut. Dan rangsangan kognisi untuk memahami kandungan-kandungan berbagai aspek didalamnya.

Pendidikan harus dapat meninggkatkan rasa keingin tahuan. Erat kaitanya keingintahuan dengan keaktifan siswa, dimana rasa penasaran akan memposisikan seseorang pada tindakan pemenuhan hasrat akan sesuatu yang belum ia mengerti. kesenian Laras Madya adalah objek baru yang menempatkan siswa sebagai seseorang yang belum mengerti, dengan menyuguhkan instrument-instrument kesenian Laras Madya yang cenderung simpel, akan memberikan rasa penasaran dan keingintahuan siswa. Biarkan siswa bereksplorasi dengan instrumen-instrumen tersebut dan pancing untuk menanyakan sesuatu sebelum diajarkanya tata cara permainan kesenian Laras Madya secara benar dan sistematis. Melalui pengamatan dan pertanyaan-pertanyaan siswa akan lebih banyak belajar tentang sesuatu hal dan membuka wawasan mereka untuk mengetahui lebih dalam mengenai kesenian Laras Madya dan konteks-konteks yang melingkupinya. Hal tersebut merupakan tahapan menuju sebuah kepuasan pada 
diri siswa, oleh karena titik keingintahuan yang terpenuhi dalam pembelajaran yang aktif dan menyenangkan.

Pendidikan harus dapat menimbulkan kepekaan. Kesenian Laras Madya sebagai materi pelajaran kesenian dan budaya juga berkontribusi dalam kepekaan personal siswa baik melalui pemahaman intra estetik maupun ekstra estetiknya. Ajaklah siswa untuk memahami peran personal sebagai seorang penabuh setiap instrumen pada kesenian ini, dimana setiap elemenya memiliki peran tersendiri berbeda satu sama lain namun saling melengkapi. Dibutuhkan kepekaan untuk saling memahami satu sama lain agar penyajian kesenian Laras Madya dapat berjalan baik, baik kepekaan dalam bermusik ataupun kepekaan pemahaman pemikiran masing-masing personal. Kepekaan pemahaman dalam lingkup kesenian itu sendiri, ataupun kepekaan kandungan interdisiplin ilmu yang berhubungan.

Selain lima orientasi diatas, diharapkan pula kesenian Laras Madya sebagai produk tradisi yang aplikatif dalam pendidikan seni memiliki pengaruh positif lebih. pendidikan seni merupakan pendidikan sikap estetis guna membantu membentuk manusia seutuhnya yang seimbang dan selaras dengan perkembangan fungsi jiwa, perkembangan pribadi yang memperhatikan lingkungan sosial, budaya, dan dalam hubungan dengan Tuhan (Jazuli, 2008: 61).

Nilai positif Laras Madya juga dapat diperoleh dari kandungan syair-syair serat wulangreh dalam tembangnya. Harsono dalam bukunya yang berjudul "Tafsir Ajaran Serat Wulangreh" mengemukakan nilai-nilai yang dapat diambil dari ajaran serat wulangreh antara lain: ajaran memilih guru, kebijaksanaan dan bergaul, kepribadian, tema tata krama,ajaran berbakti pada orang lain, tema ketuhanan, berbakti kepada pemerintah, pengendalian diri, tema kekeluargaan, tema keselamatan, keikhlasan dan kesabaran, beribadah dengan baik, ajaran tentang keluhuran.

\section{KESIMPULAN}

Pengetahuan yang diperoleh dan dibentuk melalui artistik dapat mebentuk kecerdasan melalui cara brfikir yang kreatif. Sehubungan dengan keberadaan seni sebagai disiplin yang sarat dengan nilai, maka Gage dan Berliner menjelaskan lima orientasi nilai dalam pendidikan seni yaitu: peningkatan nilai kepribadian, mengembangkan kecakapan hidup, meningkatkan kreativitas dan koognisi, 
meninggkatkan rasa keingin tahuan, menimbulkan kepekaan. Selain lima orientasi diatas, Jazuli berpendapat pendidikan seni merupakan pendidikan sikap estetis guna membantu membentuk manusia seutuhnya yang seimbang dan selaras dengan perkembangan fungsi jiwa, perkembangan pribadi yang memperhatikan lingkungan sosial, budaya, dan dalam hubungan dengan Tuhan.

Kesenian tradisional adalah salah satu materi yang relevan dalam pendidikan seni budaya, begitupun kesenian Laras Madya merupakan salah satu kesenian tradisional dari budaya Islam Jawa yang syarat dengan kandungan-kandungan nilai luhur yang berguna bagi perkembangan karakter personal. Penulis berpendapat bahwa kesenian tersebut berguna jika diaplikasikan dalam dunia pendidikan sebagai salah satu materi mata pelajaran seni budaya dalam pendidikan formal, dengan begitu siswa dapat memahami kesenian Laras Madya melingkupi sejarah, instrumentasi, penyajianya, dan nilai yang terkandung didalamnya, sebagai bentuk upaya pelestarian tradisi dan pendukung kemajuan pendidikan di Indonesia.

\section{Daftar Pustaka}

Liliweri, Alo. 2014. Pengantar Studi Kebudayaan. Bandung: Nusamedia.

Hauser, Arnold. 1982. The Sosiology of Art. Alih Bahasa ke dalam bahasa Inggris oleh Kenneth J. Northcott. Chicago: University of Chicago.

Jazuli, M. 2008. Paradigma Kontekstual Pendidikan Seni. Semarang: Unesa University Press.

Jazuli, M. 2014. Sosiologi Seni Edisi 2, Pengantar dan Model Studi seni. Yogyakarta: Graha Ilmu.

Jazuli. M. 2008. Pendidikan seni Budaya, Suplemen Pembelajaran Seni Tari. Semarang: UNNES Press.

Wadiyo. 2008. Sosiologi Seni. Semarang: UNNES Press.

Harsono, Andi. 2005. Tafsir Ajaran Serat Wulangreh.Yogyakarta: Pura Pustaka.

Sedyawati, Edi. 2006. Budaya Indonesia Kajian Arkeologi, Seni, dan Sejarah. Jakarta: PTRaja GrafindoPersada.

Bastomi, Suwaji. 1988. Apresiasi Kesenian tradisional. Semarang: IKIP Semarang Press.

Sugiharto, Bambang. 2013. Untuk Apa Seni. Bandung: Matahari.

Sulasman \& Gumilar. 2013. Teori-teori Kebudayaan. Bandung: Pustaka Setia.

Hartoko, D. 1993. Manusia dan Seni. Yogyakarta: Kanisius.

Brian, Hill.1999Learning and Assesement, PSYC 7010. Tke Home Exam, October.

Noviyanti, E. 2010. "Eksistensi Laras madya Dalam Perubahan Zaman". Skripsi. Yogyakarta: UIN Sunan Kalijaga. 
Jermias Hartes. 2014. "Kajian Dan Masalah Pendidikan Seni Strategi Dan Pendekatan”. Seminar Nasional Pendidikan Seni UNNES, Hal. 239-244.

Suharto.2007."Pendidikan Multikultural melalui Pendidikan Seni Musik". Seminar Nasional Pendidikan Seni UNNES, Hal. 163-170.

Malarsih.2014."Pendidikan Seni Tari Sebagai Alat Pendidikan Karakter". Seminar Nasional Pendidikan Seni UNNES, Hal. 303-313.

Syakir.2014."Progresivisme dan Implementasinya dalam Pendidikan Seni”. Seminar Nasional Pendidikan Seni UNNES, Hal. 265-270. 